\section{PENGARUH PROGRESSIVE MUSCLE RELAXATION TERHADAP KUALITAS TIDUR PENDERITA HIPERTENSI DI CILACAP SELATAN}

Jurnal Keperawatan dan Pemikiran

IImiah

Kasron (2017). Pengaruh Progressive Muscle Relaxation Terhadap Kualitas Tidur Penderita Hipertensi Di Cilacap Selatan. Nurscope. Jurnal Keperawatan dan Pemikiran IImiah.

3 (3). 20-28

\author{
Kasron $^{1}$, Susilawati ${ }^{2}$ \\ ${ }^{1}$ Program Studi S-1 Keperawatan Stikes Al-Irsyad-Al-Islamiyyah Cilacap \\ ${ }^{2}$ Program Studi D-3 Kebidanan Stikes Al-Irsyad-Al-Islamiyyah Cilacap
}

\begin{abstract}
ABSTRAK
Pendahuluan: Penderita hipertensi dapat mengeluhkan gangguan tidur seperti pusing atau sakit kepala, merasa lelah disiang hari, gelisah, konsentrasi menurun, mudah tersinggung. Tujuan penelitian ini adalah mengetahui pengaruh progressive muscle relaxation (PMR) terhadap kualitas tidur pasien hipertensi di Cilacap Selatan. Metodologi: Metode penelitian menggunakan quasi-experiment dengan pendekatan pre-post test without control group. Responden penelitian adalah pasien hipertensi di Cilacap Selatan, pemilihan responden menggunakan non-probability sampling dengan metode purposive sampling, dengan kriteria yang mengikuti prolanis aktif, mampu melakukan aktivitas mandiri, mengkonsumsi obat anti-hipertensi, melakukan PMR secara teratur selama 7 hari. Sedangkan kriteria ekslusi meliputi penderita yang ada gangguan gerak osteoarthtritis maupun rheumatoid arthtritis. Responden diukur tingkat kualitas tidur menggunakan terjemahan Pittsburgh Sleep Quality Index (PSQI) sebelum perlakuan dan 7 hari setelah pemberian PMR. Analisis statistik menggunakan Wilcoxon test. Sejumlah 16 responden memenuhi kriteria penelitian. Hasil:Sebelum perlakuan PMR sebanyak 7 orang $(43,8 \%)$ kategori kualitas tidur kurang baik dan 9 orang $(56,3 \%)$ sangat buruk. Setelah perlakuan sebanyak 3 orang $(18,8 \%)$ kategori agak baik dan 13 orang $(81,3 \%)$ kategori kurang baik. Hasil analisis menunjukan bahwa terdapat perbedaan yang kualitas tidur antara sebelum dan setelah pemberian PMR dengan $p$-value $<0,001$. Diskusi: Kesimpulan penelitian adalah terdapat perbedaan kualitas tidur antara sebelum dan setelah pemberian PMR pada penderita hipertensi di Cilacap Selatan. Perlu intervensi untuk meningkatkan kualitas tidur penderita hipertensi dengan intervensi mandiri seperti penggunaan PMR.
\end{abstract}

Kata kunci: hipertensi, kualitas tidur, progressive muscle relaxation.

\title{
THE EFFECT OF PROGRESSIVE MUSCLE RELAXATION ON SLEEP QUALITY IN PATIENTS WITH HYPERTENSION IN SOUTH CILACAP CITY
}

\section{ABSTRACT}

Introduction : Patients with hypertension patients can have sleep disorders such as dizziness or headache, feeling tired during the day, anxiety, decreasing concentration and irritability. This study aimed to evaluate the effect of progressive muscle relaxation (PMR) on sleep quality in patients with hypertension in South Cilacap City. Method : The research used quasi-experiment with pre-post test without control group. Respondents werw patients with hypertension in South Cilacap City, with the criteria forthose who were active in health care programme, able to perform independent activities, consume of anti-hypertensive drugs, have done PMR regularly for 7 days, and the exclusion criteria was patients with impaired osteoarthritis and rheumatoid arthritis. Pittsburgh Sleep Quality Index (PSQI) was used to evaluate sleep quality twice, before and 7 days after 
interventions PMR. Statistic analysis used wilcoxon test. 16 respondents included in the criteria. Result : The quality of sleep before treatment PMR was 7 people (43.8\%) poor, 9 people (56.3\%) very bad. After treatment PMR was 3 people (18.8\%) rather good, 13 people $(81.3 \%)$ less good. The analysis shown the sleep quality was difference between before and after PMR with $p$-value $<0.001$. Discussion : The study shows there is difference between before and after PMR in hypertensive patients in South Cilacap. PMR can be used to improve the sleep quality of hypertensive patients.

Keywords: hypertension, sleep quality, progressive muscle relaxation.

Corresponding Author:

Kasron, Stikes Al-Irsyad Al-Islamiyyah Cilacap, Jalan Cerme No 24 Sidanegara Cilacap 53223. E-mail : kasron@stikesalirsyadclp.ac.id

\section{PENDAHULUAN}

Hipertensi adalah tekanan darah persisten dimana tekanan sistoliknya diatas $140 \mathrm{mmHg}$ dan tekanan diastolik diatas $90 \mathrm{mmHg}$ (Mancia et al., 2013). Hipertensi disebabkan oleh banyak hal seperti adanya factor genetic dan gaya hidup yang buruk seperti merokok, minum beralkohol, konsumsi garam berlebih serta obesitas. Adanya penyakit ginjal, hipertensi vascular renal, penggunaan estrogen dan hiperaldosteronisme juga dapat menyebabkan terjadinya hipertensi (Weber et al., 2014).

Di dunia, angka kejadian hipertensi yaitu berkisar $26,4 \%$ populasi dunia dengan perbandingan $26,6 \%$ pada laki-laki dan $26,1 \%$ pada perempuan. Sedangkan angka kejadian hipertensi di Indonesia yaitu mencapai 15-20\%pada orang dewasa. Penyakit hipertensi cenderung dialami pada usia kelompok 4554 tahun dimana usia ini merupakan usia yang produktif (Cohen, 2009). Pada saat ini hipertensi merupakan faktor risiko ketiga terbesar yang dapat menyebabkan kematian dini. Hipertensi menyebabkan $62 \%$ penyakit kardiovaskular. Penyakit hipertensi diperkirakan akan terus meningkat setiap tahunnya dan pada tahun 2025 , diperkirakan $29 \%$ atau 1,6 milyar orang di seluruh dunia akan mengalami hipertensi (Nadruz, 2015).

Angka kejadian hipertensi di Kabupaten Cilacap menurut Dinkes Kabupaten Cilacap tahun 2014, hipertensi merupakan 10 penyakit terbanyak. Kasus terjadinya hipertensi di Kabupaten Cilacap pada tahun 2014 yaitu sebanyak 15.717 kasus, dengan hipertensi essensial 13.105 kasus. Di Puskesmas Cilacap Selatan 2 terjadi kasus hipertensi sebanyak 571, dan pada tahun 2016 kasus hipertensi meningkat menjadi 819 kasus. Puskesmas Cilacap Selatan 2 mempunyai Prolanis yang dilaksanakan setiap 1 bulan sekali dan pada bulan Januari 2017 terdata 35 pasien lansia dengan hipertensi yang aktif mengikut prolanis yang dilaksanakan setiap satu bulan sekali (Dinas Kesehatan Kabupaten, 2017). 
Pasien dengan hipertensi dapat mengalami beberapa tanda dan gejala seperti perubahan pada retina, sakit kepala, pusing, dan sulit bernafas. Hal ini dapat menimbulkan terjadinya masalah gangguan tidur. Gangguan tidur merupakan suatu kumpulan kondisi yang dicirikan dengan adanya gangguan dalam jumlah, kualitas ataupun waktu tidur pada seseorang individu (Nagai \& Kario, 2012). Gangguan tidur yang terjadi pada seseorang dapat mempengaruhi kualitas tidurnya menjadi buruk. Kualitas tidur akan semakin buruk seiring dengan bertambahnya usia, karena seiring bertambahnya usia maka akan terjadi proses penuaan secara degenerative. Kualitas tidur yang buruk akan berpengaruh pada menurunnya produktivitas seseorang (Javaheri, Storfer-isser, Rosen, \& Redline, 2008).

Pasien hipertensi yang mengalami gangguan pada tidurnya biasanya terbangun pada pagi hari karena merasa pusing atau sakit kepala, akan merasa lelah disiang hari, memperburuk kondisi pasien, seperti semakin kecemasan, lelah, gelisah, konsentrasi menurun, mudah tersinggung, dan dapat menimbulkan penyakit baru pada penderitanya seperti penyakit pembuluh darah koroner atau otak, obesitas, dan depresi (Persson, Clow, Edwards, Hucklebridge, \& Rylander, 2003).

Penentuan kualitas tidur seseorang dapat diukur melalui suatu instrumen. Intrumen yang dapat digunakan untuk menentukan kualitas tidur seseorang yaitu kuesioner Pittsburgh Sleep Quality Index (PSQI). PSQI telah secara umum digunakan untuk mengetahui tingakt kualitas tidur seseorang yang secara general yang menunjukan hasil yang kuat (Backhaus, Junghanns, Broocks, Riemann, \& Hohagen, 2002; Gezer et al., 2014).

Pasien dengan hipertensi biasanya memiliki kualitas tidur yang buruk, kualitas tidur yang buruk memiliki risiko lebih tinggi terjadinya hipertensi dibandingkan dengan kualitas tidur yang baik. Jika pasien hipertensi memiliki kualitas tidur yang buruk maka akan mempengaruhi tekanan darah pasien tersebut. Dimana tekanan darah akan meningkat dan akan memperburuk penyakit hipertensi yang dialami oleh pasien, sehingga kualitas tidur yang buruk pada pasien hipertensi harus diatasi (Javaheri et al., 2008).

Terapi yang bisa dilakukan untuk meningkatkan kualitas tidur dapat berupa nonfarmokologis yang dapat dilakukan dengan menggunakan relaksasi, sugesti, imajinasi, aromaterapi, terapi music, akupresure, dan terapi tertawa (G. de Niet, Tiemens, Lendemeijer, \& Hutschemaekers, 2009; G. J. De Niet, Tiemens, Kloos, \& Hutschemaekers, 2009). Salah satu teknik untuk relaksasi adalah teknik PMR Jacobson. PMR menurut Jacobson adalah suatu keterampilan yang dipelajari dan digunakan untuk mengurangi atau menghilangkan ketegangan serta menimbulkan rasa nyaman tanpa tergantung pada subjek diluar dirinya. PMR ini digunakan untuk mengurangi rasa cemas, stres, atau 
ketegangan. Dengan menegangkan sekelompok tertentu otot dan melemaskannya kembali dengan merasakan sensasi tegang dan sensasi rileks pada kelompok otot tersebut (Singh et. al, 2009).

Penelitian yang dilakukan oleh Rahman (2014) tentang penggunaan PMR pada lansia yang mengalami gangguan kualitas tidur menunjukan PMR dapat meningkatkan kualitas tidur pada pasien lansia dengan $\mathrm{p}$-value 0,005 .

\section{METODE}

Penelitian ini merupakan jenis quasi-experiment dengan pendekatan pre-post test without control group. Pada penelitian ini subjek adalah penderita hipertensi di Cilacap Selatan. Pemilihan responden menggunakan non-probability sampling dengan metode purposive sampling, dengan cara memilih sesuai dengan kriteria inklusi sampel:

a. Penderita hipertensi aktif mengikuti prolanis.

b. Mampu melakukan aktivitas mandiri.

c. Mengkonsumsi obat anti-hipertensi.

d. Melakukan PMR teratur selama 7 hari. Sedangkan kriteria ekslusi meliputi penderita hipertensi yang terdapat gangguan gerak osteoarthtritis maupun rheumatoid arthtritis.

Jumlah sampel yang digunakan 16 responden. Responden diukur tingkat kualitas tidur menggunakan terjemahan Pittsburgh Sleep Quality Index (PSQI) sebelum perlakuan dan 7 hari setelah pemberian PMR. Analisis statistik menggunakan Wilcoxon test. Sejumlah 16 responden memenuhi kriteria penelitian.

\section{HASIL}

Tabel 1. Karakteristik Responden

\begin{tabular}{llll}
\hline No & Karakteristik & F & \% \\
\hline 1 & Usia & & \\
& $<60$ Tahun & 6 & 37,5 \\
& 60-64 Tahun & 5 & 31,3 \\
& $>64$ Tahun & 5 & 31,3 \\
2 & Jenis kelamin & & \\
& Perempuan & 13 & 81,3 \\
& Laki-laki & 3 & 18,8 \\
3 & Pendidikan & & \\
& SD & 8 & 50,0 \\
& SMP & 3 & 18,8 \\
& SMA & 5 & 31,3 \\
\hline
\end{tabular}


Sebagian besar responden berusia kurang dari 60 tahun (37,5\%), hampir seluruh responden perempuan $(81,3 \%)$ dan separuh responden berpendidikan SD (50\%).

Tabel 2 Analisis Intervensi PMR dan Kualitas Tidur

\begin{tabular}{llccccc}
\hline \multirow{2}{*}{ No } & \multirow{2}{*}{ Kualitas Tidur } & \multicolumn{2}{l}{ Pre PMR } & \multicolumn{2}{l}{ Post PMR } & \multirow{2}{*}{-value* } \\
\cline { 2 - 6 } & & $\mathbf{F}$ & $\%$ & $\mathbf{F}$ & $\%$ & 0,001 \\
\hline 1 & Sangat Baik & 0 & 0 & 0 & 0 & \\
2 & Agak Baik & 0 & 0 & 3 & 18,8 & \\
3 & Kurang Baik & 7 & 43,8 & 13 & 81,3 & \\
4 & Sangat Buruk & 9 & 56,3 & 0 & 0 & \\
\hline
\end{tabular}

Uji Wilcoxon, Bermakna pada $p$-value $<0,05$.

Tabel 2 menunjukan bahwa sebelum perlakuan PMR 43,8\% responden dengan kualitas tidur kurang baik dan 56,3\% responden kualitas tidur sangat buruk. Setelah perlakuan PMR 18,8\% responden dengan kualitas tidur agak baik dan $81,3 \%$ kualitas tidur kurang baik, hasil analisis selanjutnya menunjukan bahwa terdapat perbedaan kualitas tidur sebelum dan setelah pemberian PMR pada penderita hipertensi dengan $p$ value 0,001 .

\section{PEMBAHASAN}

Hasil penelitian menunjukan sebelum perlakuan sebanyak $56,3 \%$ responden dengan kualitas tidur sangat buruk, sedangkan setelah perlakuan tidak ada responden yang dengan kualitas tidur sangat buruk. Hasil analisis menunjukan sebelum dan setelah PMR terdapat perbedaan kualitas tidur yang bermakna dengan dengan $p$-value 0,001. Hasil penelitian sejalan dengan penelitian oleh Saeedi et al. (2012) tentang penggunaan PMR untuk meningkatkan kualitas tidur pada pasien yang dilakukan hemodialisis, yang menunjukan bahwa kualitas tidur pasien meningkat setelah diberikan PMR dengan p-value <0,001 (Saeedi et al., 2012). Sejalan dengan penelitian oleh Richardson (2003) tentang penggunaan PMR menunjukan pengaruh terhadap kualitas tidur pasien yang di rawat di bangsal kritis dengan penyakit terminal (Richardson, 2003). Penelitian lain oleh Sheu et al. (2003) tentang penggunaan PMR pada pasien hipertensi essensial menunjukan bahwa setelah intervensi 4 minggu pasien hipertensi mengalami penurunan rata-rata $5,44 \mathrm{mmHg}$ untuk sistoloik, dan 3,48 $\mathrm{mmHg}$ untuk diastolic. Hasil menunjukan secara signifikan menurunkan tekanan darah pada pasien hipertensi (Sheu et al., 2003).

PMR adalah kontraksi dan relaksasi berulang-ulang dari kelompok otot yang berbeda. Dengan melakukan penegangan dan pengenduran otot maka dapat menurunkan input dan output motor neuron, yaitu pada pre presinap akan menurunkan kontrol refleks $\mathrm{H}$ (proprioseptif) pada post sinap akan menurunkan kontrol refleks E (eksteroseptif). Penurunan proprioseptif dan ekteroseptif akan 
mengakibatkan penurunan motor evoked potensial (MEP) yang selanjutnya akan menurunkan aktifitas skeletal-motor system, sistem saraf otonom (simpatis dan parasimpatis) dan jaras kortikal (Guissard, Duchateau, \& Hainaut, 2001). Penurunan aktifitas skeletal-motor system dapat merelaksasikan sistem fisik seperti otot-otot tubuh. Pada sistem saraf otonom akan melibatkan sistem saraf simpatis dan sistem saraf parasimpatis. Beberapa organ dipengaruhi oleh kedua sistem saraf ini, aktifasi dari sistem saraf simpatik disebut juga erotropic atau respon figh or flight dimana efek dari saraf simpatis, yaitu meningkatkan denyut nadi, tekanan darah, hiperglikemia, dan dilatasi pupil, pernafasan meningkatkan, serta otot menjadi tegang. Aktivitas dari sistem saraf parasimpatis disebut juga trophotropic yang akan memanipulasi hipotalamus dengan menyebabkan rasa relaks dan lebih nyaman secara fisiologis dan emosional, serta dapat menyebabkan perasaan ingin istirahat, dan perbaikan fisik tubuh. aktivas ini merupakan dasar respon relaksasi dimana respon parasimpatik meliputi penurunan denyut nadi dan tekanan darah, perubahan fungsi neuroendokrin serta meningkatkan aliran darah. Oleh sebab itu melalui latihan relaksasi dapat memunculkan respon relaksasi sehingga dapat mencapai keadaan tenang. Penurunan pada jaras kortikal dan hipotalamus dapat menyebabkan sensasi rileks dan tenang secara psikologis emosional (Conrad \& Roth, 2007). Mekanisme kerja progresive muscle relaxation dalam mempengaruhi kebutuhan tidur yaitu karena terdapat gerakan kontraksi dan relaksasi otot yang dapat menstimulasi respon relaksasi baik fisik maupun psikologis. Ketika melakukan gerakan relaksasi otot, sebuah sel syaraf juga mengeluarkan opiate peptides dan dialirkan keseluruh tubuh sehingga yang dirasakan adalah rasa nikmat dan rileks. Adanya respon relaksasi trophotropic akan menstimulasi sistem saraf. Dimana fungsi sistem saraf berlawanan dengan sistem saraf simpatis sehingga tercapai keadaan rileks dan tenang. Perasaan rileks ini akan diteruskan ke hipotalamus sehingga hipotalamus menghasilkan Corticotropin Releasing Factor (CRF). CRF akan menstimulasi kelenjar pituitary sehingga produksi beberapa hormone akan meningkat, seperti B-endorphin, enkefalin dan serotonin. Secara fisiologis, kebutuhan tidur akan terpenuhi karena akibat dari penurunan aktivitas Reticular Activating System (RAS) dan noreepineprine sebagai akibat penurunan aktivitas sistem batang otak. Respon relaksasi akan terjadi karena adanya aktifitas sistem saraf otonom parasimpatis nuclei rafe. Hal ini akan menyebabkan perubahan yang dapat mengontrol aktivitas sistem saraf otonom berupa pengurangan fungsi oksigen, frekuensi nafas, denyut nadi, ketegangan otot, tekanan darah, serta gelombang alfa dalam otak sehingga mudah untuk tertidur (Brunelli et al., 2015).

Progressive muscle relaxation dapat mempengaruhi tidur karena saat melakukan PMR akan memunculkan respon relaksasi (Trophotropic) yang menstimulasi semua fungsi dimana kerjanya berlawanan dengan system saraf simpatis sehingga tercapai keadaan rileks dan tenang. Perasaan 
rileks akan menghasilkan Corticotropin Releasing Factor (CRF) sehingga meningkatkan produksi beberapa hormone, seperti B-Endorphin, Enkefalin dan Serotonin (Ramdhani, 2008). Secara Fisiologis, terpenuhinya kebutuhan tidur terjadi karena penurunan aktifitas Reticular Activating System (RAS) dan noreepineprine sebagai akibat penurunan aktivitas sistem batang otak, sebagai akibat dari penurunan aktivitas Reticullar Activating System (RAS) dan peningkatan aktivitas batang otak akan menimbulkan sensasi nyaman sehingga merangsang timbulnya kantuk. (Feldman, Greeson, \& Senville, 2010).

Hasil penelitian menunjukan terdapat pengaruh pemberian progressive muscle relaxation dengan kualitas tidur penderita hipertensi di Cilacap Selatan, sehingga penderita hipertensi dapat melakukan PMR untuk meningkatkan kualitas tidur yang terganggu akibat dari hipertensi yang diderita.

\section{SIMPULAN DAN SARAN}

\section{Simpulan}

Terdapat perbedaan kualitas tidur antara sebelum dan setelah pemberian intervensi progressive muscle relaxation pada penderita hipertensi di wilayah kerja Puskesmas Cilacap Selatan 2.

\section{Saran}

Perlu intervensi untuk meningkatkan kualitas tidur dengan intervensi mandiri seperti penggunaan PMR pada penderita hipertensi di Cilacap Selatan.

\section{KEPUSTAKAAN}

Backhaus, J., Junghanns, K., Broocks, A., Riemann, D., \& Hohagen, F. (2002). Test - retest reliability and validity of the Pittsburgh Sleep Quality Index in primary insomnia. Journal of Psychosomatic Research, 53, 737-740.

Brunelli, S., Morone, G., losa, M., Ciotti, C., Giorgi, R. De, Foti, C., \& Traballesi, M. (2015). Efficacy of Progressive Muscle Relaxation, Mental Imagery, and Phantom Exercise Training on Phantom Limb : A Randomized Controlled Trial. Archives of Physical Medicine and Rehabilitation, 8-12. http://doi.org/10.1016/j.apmr.2014.09.035

Cohen, J. D. (2009). Hypertension Epidemiology and Economic Burden : Refining Risk Assessment To Lower Costs. Managed Care, (October), 51-58.

Conrad, A., \& Roth, W. T. (2007). Muscle relaxation therapy for anxiety disorders: It works but how? Journal of Anxiety Disorders, 21(3), 243-264. http://doi.org/10.1016/j.janxdis.2006.08.001

de Niet, G., Tiemens, B., Lendemeijer, B., \& Hutschemaekers, G. (2009). Music-assisted relaxation to 
improve sleep quality: meta-analysis. Journal of Advanced Nursing, 65(7), 1356-1364. http://doi.org/10.1111/j.1365-2648.2009.04982.x

Dinas Kesehatan Kabupaten. (2017). Laporan Tahunan Penyakit Tidak Menular (PTM). Cilacap.

Feldman, G., Greeson, J., \& Senville, J. (2010). Behaviour Research and Therapy Differential effects of mindful breathing, progressive muscle relaxation, and loving-kindness meditation on decentering and negative reactions to repetitive thoughts. Behaviour Research and Therapy, 48(10), 1002-1011. http://doi.org/10.1016/j.brat.2010.06.006

Gezer, O., Batmaz, I., Sariyildiz, M. A., Sula, B., Gezer, O., Ucmak, D., ... Nas, K. (2014). Sleep quality in patients with psoriatic arthritis. International Journal of Rheumatic Disessases, 1-7.

Guissard, N., Duchateau, J., \& Hainaut, K. (2001). Mechanisms of decreased motoneurone excitation during passive muscle stretching. Experimental Brain Research, 137(2), 163-169. http://doi.org/10.1007/s002210000648

Javaheri, S., Storfer-isser, A., Rosen, C. L., \& Redline, S. (2008). Sleep Quality and Elevated Blood Pressure in Adolescents. Circulation, 118, 1034-1040. http://doi.org/10.1161/CIRCULATIONAHA.108.766410

Mancia, G., Fagard, R., Narkiewicz, K., Redon, J., Zancetti, A., Bohm, M., \& Christien, T. (2013). 2013 ESH / ESC Guidelines for the management of arterial hypertension The Task Force for the management of arterial hypertension of the European Society of Hypertension ( ESH ) and of the European Society of Cardiology ( ESC ). Blood Pressure, (early online), 1-86. http://doi.org/10.3109/08037051.2013.812549

Nadruz, W. (2015). Myocardial remodeling in hypertension. Journal of Human Hypertension, 29(1), 16. http://doi.org/10.1038/jhh.2014.36

Nagai, M., \& Kario, K. (2012). [Sleep disorder and hypertension]. Nihon Rinsho. Japanese Journal of Clinical Medicine, 70(7), 1188-1194.

Niet, G. J. De, Tiemens, B. G., Kloos, M. W., \& Hutschemaekers, G. J. M. (2009). Review of systematic reviews about the efficacy of non-pharmacological interventions to improve sleep quality. International Journal Evidence Based Healthcare, 7, 233-242. http://doi.org/10.1111/j.17441609.2009.00142.x

Persson, K., Clow, A., Edwards, S., Hucklebridge, F., \& Rylander, R. (2003). Effects of nighttime low frequency noise on the cortisol response to awakening and subjective sleep quality. Life Science, 72, 863-875.

Richardson, S. (2003). Effects of Relaxation and Imagery on the Sleep of Critically III Adults. Dimensions of Critical Care Nursing, 22(4), 182-190. 
Saeedi, M., Ashktorab, T., Saatchi, K., Zayeri, F., Amir, S., \& Akbari, A. (2012). The Effect of Progressive Muscle Relaxation on Sleep Quality of Patients Undergoing Hemodialysis. Iranian Journal of Critical Care Nursing, 5(1), 23-28.

Sheu, S., Irvin, B. L., Lin, H.-S., \& Mar, C.-L. (2003). Effects of Progressive Muscle Relaxation on Blood Pressure and Psychosocial Status for Clients with Essential Hypertension in Taiwan. Holistic Nursing Practice, 17(1).

Singh, V. P., Rao, V., V, P., R C, S., \& K, K. P. (2009). Comparison of the effectiveness of music and progressive muscle relaxation for anxiety in COPD--A randomized controlled pilot study. Chronic Respiratory Disease, 6(4), 209-216. http://doi.org/10.1177/1479972309346754

Weber, M. A., Schiffrin, E. L., White, W. B., Mann, S., Lindholm, L. H., Kenerson, J. G., ... Ram, C. V. S. (2014). Clinical Practice Guidelines for the Management of Hypertension in the Community A Statement by the American Society of Hypertension and the International Society of Hypertension. The Journal of Clinical Hypertension, 16(1), 14-26. http://doi.org/10.1111/jch.12237 